\title{
Poetry v/s Power: A Reading of 100 Poets Against the War
}

\author{
Prof. Majeed U. Jadwe and Instr. Omar Sadoon Ayed \\ University of Anbar-College of Arts. Iraq.
}

\begin{abstract}
This essay critically examines the invocation of poetry as a strategy of ethical resistance against the war on Iraq in the chapbook anthology 100 Poets Against the War, which was assembled in a matter of few weeks before the war. . This textual tactics figures prominently among other resistance tactics employed by the poets in the 100 poems included in this anthology. Considerable number of poems turns to the invocation of poetry, the act of poetry making, and the power of the poem as a means to initiate an inquiry into the injustice of the war and the ethical responsibility of poetry to counter this injustice. Although 100 Poets Against the War emerges with one powerful collective voice which transcends cultural and racial barriers, this thematic strand of poetry invocation to counter the war on Iraq remains quite recognizable and, in a sense, foregrounds this collective voice.
\end{abstract}

KEYWORDS: antiwar poetry, ethical resistance, invasion of Iraq, anthologies, invocation of poetry

\section{Introduction}

100 Poets Against The Waris an anthology of 100 anti-war poems, by various poets from all over the world, which was assembled by Todd Swift in a matter of weeks to protest the upcoming war on Iraq. It made its first appearance on the internet in the form of an electronic "chapbook anthology," to quote its editor (1).It was uploaded to the internet for free download on the Nth Position website www.nthposition.com and later in 2003 published by Salt into print book form. This anthology first hit the internet on January 27, 2003, the day on which Hans Blix, head of the Iraq weapons inspection team, delivered his decisive reportto the security council of the United Nations.

Swift succeeded to create a powerful poetic cry against the war on Iraq by utilizing the great potential of the anthology form and the electronic space of the Internet. These two elements ensured a work of global reach, a kind of a world-wide protest against this war. The e-mail gave him quick contact with fellow poets all over the world whereas the electronic space of the world-wide web provided him with the medium to anthologize the poems he received through e-mails into a unified whole, which would also affectively reach a wider audience at computers terminals. This resulted in a dynamic interaction between the 100 poets and their audience all over the Globe, a quality which make this anthology a sharp cry against the war. Swift speaks to this effect when he states, in the short preface to this anthology, that:"100 Poets Against The War is proof that well-written (political) poetry does happen, and matters: it reveals powerfully (and poignantly) how many people oppose imperialist wars of aggression, or want peace, rather than full spectrum domination" (1).

This statement is an important key to understand the significance of this poetic anthology. "Poetry does happen" in the sense that this hurriedly put up work did actually, though for a brief span, restore poetry its full energy and vitality as a communal-cultural activity. But how does it come to 'happen', i.e., materialize as affect? One possible way is through the politics of resistance it (un)consciously fashions to counter the impending war on Iraq. Most of the poems in this anthology engage in an active resistance/negotiation of war/ and the war to come, and by extension an inquiry into the power of poetry as an act of cultural resistance. This anthology succeeded to counter or resist war because the contributing poets succeeded, in Dean Brink's words, to "break away from standard I-centre poetry and build poetry in a reportage mode, engaging the implied others in articulations assuming accountability, not merely irony" (4).These voices, continues Brink, were not merely opposing the war on Iraq as a passing facet of their poems, nor they fall in the trap of "aesthetic zing and reflexive gestures, as if ata loss as to how to articulate resistance or seed critical foundations." (4) 
Because these poems were mostly written in the context of call and response, they all exhibit a vivid sense of immediacy of purpose and active combatant spirit. They forego with poetic formalism and anesthetizations in favor of a more direct and confrontational verse. This freshness and originality also spring from the poets' staunchest belief in the power of poetry as the ultimate form of cultural resistance to counter war and the ideological rhetoric underlying it. Each of their poems becomes, overtly or covertly, an act of resistance to the impending invasion of Iraq. One significant textual tactic is to fashion the act of poetic creation as an act of cultural resistance. In his analysis of Swift's anthology, Suman Gupta identifies "a stark confrontation of war by poetry itself, without mediating contextsand affiliations and allegiances, because poetry is widely regarded as moral, peace-loving, the medicine for the ailment of war just by being poetry" (59). This means that this anthology is not only anti-war, continues Gupta, but "anti-war by beingpro-poetry where poetry is understood as implicitly a pacifist medium" (59). Thus, poetry is invoked in this anthology because of its oppositional nature to war and violence.

This power of poetry to counter the aggressive discourse of war and home politics of invasion highlights the materiality of poetry as a 'thing' that can reach beyond words and rhetoric. Considerable number of poems plays on this warring conception of poetry in their reception of the Iraq war and the imperialist jargon underlying it. In such poems the act of poetry creation, its recitation, and any other issue relevant to the poetic act are invoked as textual spaces to mediate and, ultimately, negotiate the idea of war as an ideological discourse. Poet Susan McMaster, for instance, overtly employs such textual invocation of the power of poetry to resist the upcoming Iraq War with poetry as weapon in her poem "Against the War":

\author{
Against the war I'll recite \\ this poem on Wellington Street, \\ ....... \\ Against the war I'll act \\ today, as I can, for peace. (5-6/30-31)
}

She equates poetry with action as an act of resistance against the war by framing 'this poem' in a double context: one has to do with recitation as an oral act of protest with all its charged suggestiveness of ritualism. "I'll recite", then, imbues 'this poem' with the power of holiness; it becomes a little prayer against the war. The second context is that of 'Willington Street' where massive anti-war protests outbroke on the eve of war on Iraq. This acts to distance her poem into historicity, an archive of the times. This brings her poem a full circle into an 'act' which makes here resistance of war 'happen'.

Because the materiality of poetry in this anthology stems from the materiality of war itself, the historical consciousness of the temporal moment of the pending Iraq war is of paramount significance in the textual tactics of the act of poetic resistance. Susan McMaster's anti war poem, like almost each poem in this anthology, seeks to capture/defamilarizes the historicity of the Iraq war moment to contest both history and war. What is actually contested here is the eventfulness of the history made by war, and by proxy, Western ideology. Poetry in this anthology simply refuses to perform its conventional job. It refuses to chronicle the temporal consciousness of this war-made-history. It is simply resistive of this consciousness.

Similarly, the poet Neeli Cherkovski employs the historical context of these massive protests to highlight the resistive powers of poetry against the war on Iraq. He speaks to this effect in the final stanza of his poem "After the Anti War March":

\author{
It's the day after the march, I should \\ have been there, but here I am now \\ walking through my words to where \\ we must reclaim the land and its language (25-28)
}

This stanza stands in sharp contrast to the preceding four stanzas which were focusing on the war rhetoric of George Bush, his defense secretary, and his national security advisor. It presents both the poet's ethical stand against the war and his active engagement with poetry as a means of resistance to this war. The historical context of the marches of 2003 lends power to his words/verses not only to counter the official American war rhetoric but, ultimately, to 'reclaim the land and its language', i.e., to restore our humanity through the sacredness of poetry. 
The poet, here, may not be that divine Coleridgean figure but another fellow poet, Margo Berdeshevsky, makes this quite clear in a poem called "Who Shall Be Hung", with its direct and rich allusion to the crucifixion of Jesus Christ to redeem the fallen human world.

I shall be hung. Who shall be hung, all souls, our damp impatience for - I think that time's invented helm is wacky spinning Weimar bodies, think it's spewing signs we can't elude, this night a poet prays, her head lolling and as though in her own bottle-glass-eye, blind too, she now can see

a blade's truth of it, (8-14)

The rugged blank verse echoes the sweeping grandeur of Miltonic song of the Biblical fall in Paradise Lost. But the resemblance is far greater than a textual echo for Berdeshevsky's poem starts with a $21^{\text {st }}$ century version of Lucifer:

How he writhes, bottle-eyed animal moaning for an eager war, how a president stamps for orgasm not to be denied for now his troops are massed and time, the all we have, chanting. (1-3)

The allegory is more than obvious with a Lucifer-like George W. Bush stands with his amassed army in a historical moment similar to that Biblical one of disobedience and damnation. The only redemption left lies in the power of 'chanting', i.e., poetry. The act of poetry becomes a holy act of hanging on the cross of imagination. So on this night of the 'Last Supper' on the eve of the war on Iraq, it is 'a poet prays' to stop this war. But the final image of the poet is less Jesus-like and far closer to that mythological prophet of Apollo, the blind Tires as, who 'can see a blade's truth of it', i.e., the truth and consequences of the war on Iraq.

However, this Parnassian grandeur is not always the rule among the individual poems of the anthology. Some poems, like "A verse to war" by J R Carpenter, are not even sure of the efficacy of poetry to counter/resist the inevitability of the impending war on Iraq. The refrain 'I am afraid' and the short trimmed lines and the lean shape of the whole verse libre poem are skillfully employed to reflect the uncertainty and doubt of the poet about the power of his poetic medium to resist the war.

I am afraid

(of what will happen

of the rhetoric

of the silence

of not knowing).

I am afraid I don't know what to contribute. (1-6)

The phobic/paranoid voice goes on cataloging his/her worries and obsessions in form similar to the formlessness of the interior monologue. The chaos of the ceaseless succession of thoughts and confusion aptly mirrors the speaker's phobic/paranoid mentality:

\author{
I am afraid \\ (of destruction \\ of waiting \\ of doing nothing \\ of adding fuel to the flames). \\ I am afraid I don't have any answers. \\ I am afraid \\ (of trivializing \\ of propagandizing \\ of margins \\ of error). (7-17)
}


The clipped form of the poem mirrors its rhetorical strategy of mingling the poet's fear of his failure to stand up to this occasion with the terror and atrocity of the war situation. His silence and creative impotence are not signs of his failure as a poet but are due to the bigness of the war event and his fear that he might add, rather the, repelling it. The final series of of-verb phrases cast ironic light on his worries and obsessions to reflect on the deteriorating situation of poetry at the present time. Poetry has turned from a divine and sublime creative act of creation into consumerism (trivializing), TV/political commercialism (propagandizing), clerical/office routine (margins \& errors). No wonder that he worries that his antiwar poem might be another commercial product set for cheap consumption:

I am afraid it is but a meager thing to add a verse adverse to war. (18-19)

It is not only that war is inevitable and cannot be stopped whatever but that poetry lost its divine powers. A poem becomes 'a meager thing', little and ineffectual. It is no longer an act of divine creation. The verb 'to add' is used to sharpen the irony by distancing all poetry as ineffectual and out of tune. His poem would eventually be a mere 'verse adverse to war'. The play on verse/adverse is profound as verse becomes an ad(vertisment) verse. Poetry has double debased; once as verse, which is the mechanical side of poetry, and secondly as a form of commercialism, as an advertisement to war. This would eventually give an insight into the nature and cause of the poet's worries. It is not the failure of poetry or the poet to stand up to its mission but that war and the commercial culture behind the war have corrupted poetry itself and turned it into verse and advertisements. Furthermore, the assonance on consonant sounds in 'verse' and 'reverse' creates a jarring effect that is meant to echo the hissing of the heating atmosphere at the eve of the Iraq invasion. The choice of the word 'adverse', however, is highly suggestive. The grammatical context of this sentence would normally favor the more dynamic word 'against' instead of adverse. But the poet used the more passive 'adverse' to highlight his status as a poet and the inefficacy of poetry as an effective counter to the impending war.

This same feeling of disappointment with poetry as an effective tool against the war seems to be a common legacy with other poets in this anthology. Eileen Tabios, for instance, employs a sharp metaphysical technique to address the failure of poetry to signify in the time of wars. In her poem "Why I want to be a Baconaut" she cries:

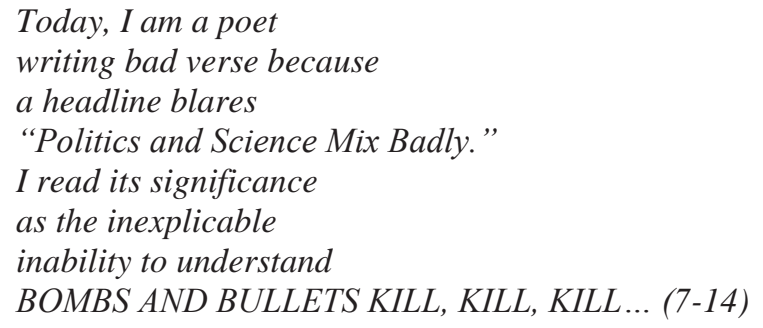

Although she identifies herself as a poet, she admits that her poetry is bad when it comes to stand for its times as the word 'today' signifies. Poetry is no longer that divine act of creation. As with J. R. Carpenter, it has become a mere act of versification as if poetry writing has become an office job. Lines of verse are substituted by journalistic headlines as an epitome of the spirit of the times.The headline is highly ironic as it replaces art, and more specifically poetry, with 'science'. This is no age for poetry. Science has become the new poetry of this age. The irony extends further as the headlines become as deep as any piece of original poetry. The poet tries hard to interpret the headline but fails because it masks a poetics of Thantos; death and nihilism. 'BOMBS AND BULLETS' replace stanzas and poems whereas 'KILL, KILL, KILL' replaces the Eros of the poetic creation; life and creativity.

Tabios, at this point, concurs with Carpenter that political ideology and the wars it promotes are the ultimate cause for the degradation of poetry at the present time. The failure of poetry to signify is the result of an ideological effacement of humanistic values. Because resistance entails/presupposes power, in the oppressive ideological sense, Tabios's poem, like almost each poem in this anthology, acts as an act of resistance to the ideological discourse promoting war rather than war itself as a human act. The pending Iraq war as such is fashioned as an ideological signified. One important bearing of this textual tactics manifests itself in the representation of war as inevitable. This strong sense of inevitability of Iraq war casts each poem, and the anthology as a whole, as acts of doomed defiance. This is actually the textual threshold for the negotiation of the role and efficacy of poetry in the paradigm of Western 
values. Philip Metres evocates the nature of the act of resistance that these poems fashion when he states that the poems of this anthology:

Announce the poetics of war resistance, confronting the limits of lyric poetry in representing a distant war, employing identificatory rhetoric and documentary evidence, mediating between poetic disinterestedness and partisan ideology, and addressing both the nation and the peace movement. (5)

The collective voice of the whole anthology engenders a politics of resistance in its inquiry into the role and nature of poetry in relation to war as both an abstract notion and an historically-bound issue. Put in other words, the collective voice of the anthology negotiate the idea of war through the agency of poetry and, thereby, initiate an inquiry into the limits and power of poetry itself.

Susan Freeman's poem "Sim Shalom" is perhaps exemplary of this resistive negotiation of the efficacy of poetry in the paradigm of Western values. Amidst the apocalyptic scene of the destroyed city and the twelve 'mourning doves' Freeman cries desperately:

\author{
I stand alone in the turning garden \\ lifting a song for the ash-covered city, \\ for its tumbled dead and the living \\ who search, exhausted, remembering life. (9-12)
}

The 'song', i.e., the poem is all that is left to defend oneself and all human existence as well, in a world of utter destruction. The lines invoke the horror of Biblical apocalypse: the 'garden' is reminiscent of sin and fall while ash and the living-dead invoke doomsday. In this utter nihilism contemporary man has lost his/her sense of humanity and it is left to the power of the 'song'/poetry to revive that sense anew. But the song fails in a world of conflicting ideologies and power contention:

The doves offer no song, absolutely still in the bitter day.

The weight of war clouds the sky

and twelve birds sit watching. (23-25)

This is an allegory of how capitalist ideology inscribes war as the ultimate power paradigm. The 'dove' is a double symbol of peace and of the poet praying for peace. He declares his/her failure to sing/pray for his/her song/poem is quite ineffectual to counter or resist the war discourse and the ideology promoting it. War is not only inevitable but also becomes a human condition, a discourse to define human existence. No wonder that the war is perceived as a burden for humanity and nature. It is something not natural and inhuman as well. It has 'weight' and 'clouds' conceptually suggests that it is a burden and a contamination at the same time. The 'twelve birds' are said to 'sit watching', not singing, since the song is for peace. This conceptualizes the birds, not doves, as an allegorical reference to either the twelve members of the United Nations Security Council, which are passive watchers of war, if unwilling to stop it. Or it might refer to the twelve months of the year since the poem frames the poet's song in a seasonal cycle in the 'garden' of the fallen world. This would lend war the powers of human historicity. This projection of temporality makes war an eternal aspect of humanity. It is our sin and fall against us.

So, is poetry culturally dead in present day America? This might be the case as Danika Dinsmore argues in her poem "On the night she didn't feel like it anymore", where she personifies America as a housewife, at the eve of the Iraq War, who "stuffed herself to claustrophobic proportions". This is the image of America at the brink of exhaustion and purposelessness. That woman/America is caught baking and baking ceaselessly. But that woman is sad and frustrated as :

\title{
she had been startled the week before by a strange man in the yard tonight \\ she baked without looking out the window (5-7)
}

Could that 'strange man in the yard' be that war monger George W. Bush or is it an allegory for the alien muscular values that took possession of America's essential goodness. The patriarch overshadows the matriarch in the cultural history of America. The metaphor of baking is essentially motherly and connotes mercy, feeding, and charity. No 
wonder that the woman/America is seen baking all the time, feeding a whole world. When the shadowy male appears in the yard the baking continues but the woman looks like being imprisoned or, at least, without spirits. Given that the window is the conventional metaphor for life or perspective on life, the baking woman/essential America loses her/its worldview and stagnates into a sort of cultural death. This reading is fully supported by the possible reasons that the poem thereafter catalogues for this impasse. Although no cause was singled for favor, the death of poetry sprung surprisingly in the list:

perhaps a lot of poets had died in the last few weeks and with them their hats (15-16)

This possibility does not linger without the historical/temporal context of 'the last few weeks'. Poetry failed to stop the war on Iraq in spite of the weeks of intense protests in the major capitals of the world. Treating poets' death in the plural does suggest a massacre of cultural values of traditional America. The reference to 'their hats' might be ironic but highly suggestive of the lost dignity of poetry. But poetry cannot die or pass away as it is the very soul of America, so the last few lines reframes the woman as a poet at the eve of the war on Iraq in a manner reminiscent Tennyson's Lady of Shallotte. Like the lady's weaving, baking becomes a metaphor for poetry, but in both cases it is poetry facing a cultural impasse. Dinsmore's woman, however, is more anguished:

what she really wanted was to stay up all night creating a path

of words burning clay singeing the wick of mortal time (20-21)

This invocation of language, notably, poetic language is highly significant. She wants to revive the sacredness of this language from the effacement of the political language in present day America. Martin Espada writes, in this respect,:

the language of poetry is powerful precisely because it is not the language of power. Phrases such as 'weapons of mass destruction, 'and their devious uses by our government to rationalize war, bleed languageof its meaning. These poets restore the blood to words. They understand the relationship between blood and words only too well. (www.poetsagainstthewar.org)

Politicians have usurped language by twisting meaning. The immediacy and functionality of language have turned into empty rhetoric. In the grid of power-relations dominant ideological discourses of war and politics have twisted language to serve its ideological purposes through media and journalism. The use of poetry as an act of cultural resistance, then, is of paramount importance in the fight to reclaim poetic language to its human values.

100 Poets Against the War did not stop the invasion of Iraq but definitely helped to expose the rhetoric of lies the Bush administration intentionally employed to misguide America and the world. The immediacy of the call and response situation of the anthology and the universal values it celebrates brought poetry to the fore in the battle to revive American true values of humanism and democracy. The poems of the anthology, and especially those drawing on poetry to resist war, may be uneven in quality but, definitely, managed to promote one unified global voice which speaks the true language of poetry against inhumanity of war.

\section{References}

[1] Brink,Dean."The Tran ideological Line in Recent American Antiwar Poetry."

[2] Canadian Review of American Studies/Revue Canadians d'e'tudesame'ricaines, 43, no. 1, 2013, pp. 1-23. (Print)

[3] Espada,Martin. "Seers Unseen: Poets of the Vietnam War," Poets Against

[4] War website.www.poetsagainstthewar.org/newsletter/news_espada.asp

[5] Gupta, Suman. Imagining Iraq: Literature in English and the Iraq Invasion. Hound mills, Basingstoke, Hampshire: Palgrave Macmillan, 2011. (Print)

[6] Metres, Philip. Behind the Lines: War Resistance Poetry on the American Home front since 1941. Iowa City: University of Iowa Press, 2007. (Print)

[7] Swift, Todd (ed.) 100 Poets Against the War. Cambridge, UK: Salt, 2003. (Print) 